\title{
The Effect of Chlorine on Spores of Clostridium bifermentans, Bacillus subtilis and Bacillus cereus
}

\author{
By LINDA R. WYATT AND W. M. WAITES \\ Agricultural Research Council Food Research Institute, Norwich NR4 ${ }_{7} U A$
}

(Received 24 February 1975)

\begin{abstract}
SUMMARY
The effect of chlorine on the germination, outgrowth, colony formation and structure of spores of Clostridium bifermentans, Bacillus subtilis var. niger and Bacillus cereus was examined. Chlorine decreased heat resistance and slowed or prevented germination and swelling, but spores that did swell were usually able to elongate to form vegetative cells. Chlorine removed protein from spores, apparently from the coat, and allowed lysozyme to initiate germination. Treatment with other agents that remove spore-coat protein increased the lethal effect of chlorine by as much as $4000-$ fold, suggesting that coat protein protects spores against chlorine.
\end{abstract}

\section{INTR ODUCTION}

Chlorine, often as hypochlorite, is widely used to kill bacteria and will rapidly oxidize proteins (for a review, see Trueman, 197I). Knox et al. (1948) first suggested that enzymes which contain SH-groups are especially sensitive to chlorine. Bacterial spores are more resistant to chlorine than vegetative cells (Phillips, 1952) but the reasons for this extra resistance are not understood. Most previous studies on spores have been confined to the effect of chlorine on colony formation. Recently, spores damaged by chlorine have been shown to lose dipicolinic acid during heating (Alderton \& Halbrook, 1971; Dye \& Mead, 1972). In this study, the strains used were: Clostridium bifermentans; a mutant of C. bifermentans which germinates more slowly than the parent strain (Wyatt \& Waites, I971); Bacillus subtilis var. niger; and $B$. cereus. We have investigated the stage at which the formation of vegetative cells from spores is blocked by chlorine treatment, and the reasons for the extra resistance of spores to chlorine.

\section{METHODS}

Organisms, spore preparation and maintenance of cultures. The strains of Clostridium bifermentans used (parent and mutant I) and the preparation and storage of spores have been described previously (Waites \& Wyatt, I97I; Wyatt \& Waites, I97I). These organisms were maintained in the reinforced clostridial medium of Hirsch \& Grinsted (1954). Bacillus cereus $\mathrm{T}$, obtained from W. L. King, Unilever Research, Sharnbrook, Bedford, and Bacillus subtilis var. niger, from Dr J. Payne of this laboratory, were maintained on nutrient agar slopes and spores were produced by growth on potato agar plates as described by Gould, Stubbs \& King (1970). After two to three days' incubation at $30^{\circ} \mathrm{C}$, the spores were collected and washed five (B. cereus) or ten (B. subtilis) times at $4{ }^{\circ} \mathrm{C}$ with glass-distilled water before resuspending in glass-distilled water and storing at $0^{\circ} \mathrm{C}$.

Treatment of spores with chlorine. Spores (about $3.5 \mathrm{mg}$ dry wt) were centrifuged, resuspended in $5 \mathrm{ml}$ of a solution of sodium hypochlorite (BDH) containing 250 mM-sodium 
phosphate buffer $\mathrm{pH} 7 \cdot 0$, incubated for 10 min at $0{ }^{\circ} \mathrm{C}$, and then washed with glass-distilled water as described previously (Wyatt \& Waites, 1973). The strength of the hypochlorite solution was estimated as free chlorine; free chlorine was measured by the Palin method (Palin, 1957) with diethyl-p-phenylene diamine (DPD) tablets (BDH) and using the extinction coefficient at $553 \mathrm{~nm}$.

Treatment of spores with dithiothreitol, urea-dithiothreitol or urea-mercaptoethanol. Spores (about $700 \mu \mathrm{g}$ dry wt $/ \mathrm{ml}$ ) were treated with $200 \mu \mathrm{M}$-dithiothreitol, with $50 \mu \mathrm{M}$ dithiothreitol in 4 M-urea (Aronson \& Fitz-James, I97I) or with 4 M-urea with Io \% (v/v) mercaptoethanol at $\mathrm{pH} 10.3$ (Gould \& Hitchins, 1963) and then washed four times with glass-distilled water by centrifugation at $4{ }^{\circ} \mathrm{C}$.

Outgrowth, colony formation and germination. Outgrowth of C. bifermentans was tested at $37^{\circ} \mathrm{C}$ in medium containing casein hydrolysate and flushed with $\mathrm{H}_{2}+\mathrm{CO}_{2}$ (90:10, v/v), while colony formation was tested on reinforced clostridial medium solidified with $\mathrm{I} \cdot 5 \%$ (w/v) agar as described previously (Waites \& Wyatt, 1974). Spores of B. cereus and $B$. subtilis were outgrown in heart infusion broth (Difco) and colony-forming ability determined by incubating for 2 days at $30{ }^{\circ} \mathrm{C}$ on nutrient agar (Oxoid) or reinforced clostridial medium (solidified with $\mathrm{I} \cdot 5 \%$ agar). Essentially the same results were achieved on both solid media. Colony counts were made in triplicate. During outgrowth, samples of 100 organisms were counted under a phase-contrast microscope and scored as phase-bright (refractile), phasedark (non-refractile), swollen, or elongated spores. In some experiments spores were heated for 10 min, either at $80{ }^{\circ} \mathrm{C}$ for B. cereus and B. subtilis, or at $70^{\circ} \mathrm{C}$ for C. bifermentans as described by Waites \& Wyatt (1974), before examination of outgrowth, colony formation or germination. Germination was measured spectrophotometrically as described by Waites \& Wyatt (197I). The concentrations of germinants which were the optimal for the species were $(\mathrm{mM}): B$. subtilis - L-alanine $\left(5^{\circ} 0\right)$, potassium chloride (100) and sodium phosphate buffer $\mathrm{pH} 7 \cdot 5(83) ; B$. cereus - L-alanine $(\mathrm{I} \cdot 0)$, inosine $(\mathrm{I} \cdot 0)$, sodium chloride $(\mathrm{I} 00)$ and sodium phosphate buffer $\mathrm{pH} 7.5(83) ; C$. bifermentans-L-alanine (50), L-arginine (5), L-phenylalanine (5), L-lactate (25), sodium chloride (IOO) and sodium phosphate buffer pH $7 \cdot 5$ (83).

Polyacrylamide gel electrophoresis of spore extracts. Extracts were made from $14 \mathrm{mg}$ dry wt of spores by treatment with $\mathrm{r} \mathrm{ml}$ hypochlorite containing $\mathrm{I} 0 \mathrm{mg}$ free chlorine, with $\mathrm{I} \mathrm{ml}$ $50 \mu \mathrm{M}$-dithiothreitol in $4 \mathrm{M}$-urea, $200 \mu \mathrm{M}$-dithiothreitol (Aronson \& Fitz-James, 1971), or with 4 M-urea plus I0 \% (v/v) mercaptoethanol (Gould \& Hitchins, I963), and added in a maximum volume of $0.2 \mathrm{ml}$ containing $100 \mu \mathrm{g}$ protein in $10 \%(\mathrm{w} / \mathrm{v})$ sucrose to polyacrylamide gels. Electrophoresis was carried out as described by Davis \& Ornstein (196I) but without the large-pore gel, in vertical columns for about $60 \mathrm{~min}$ at $5 \mathrm{~mA} /$ running tube and $4{ }^{\circ} \mathrm{C}$. Bromophenol blue $(0 \cdot 00 \mathrm{r} \%, \mathrm{w} / \mathrm{v})$ was used as a marker, and amido black $(\mathrm{I} \cdot 0 \%$, $\mathrm{w} / \mathrm{v})$ in acetic acid $(7 \%, v / v)$ as a stain. Destaining was with several changes of acetic acid $(7 \%, v / v)$ during $36 \mathrm{~h}$ at room temperature.

Spore dry weight. Dry weights were estimated spectrophotometrically. Extinction coefficients were measured at $600 \mathrm{~nm}$ and converted to spore dry weight using a standard calibration curve relating $E_{600}$ to spore dry weight.

Protein estimations. These were made by the method of Lowry et al. (195I) with bovine plasma albumin fraction V (Armour Pharmaceuticals Ltd, Eastbourne) as a standard. 


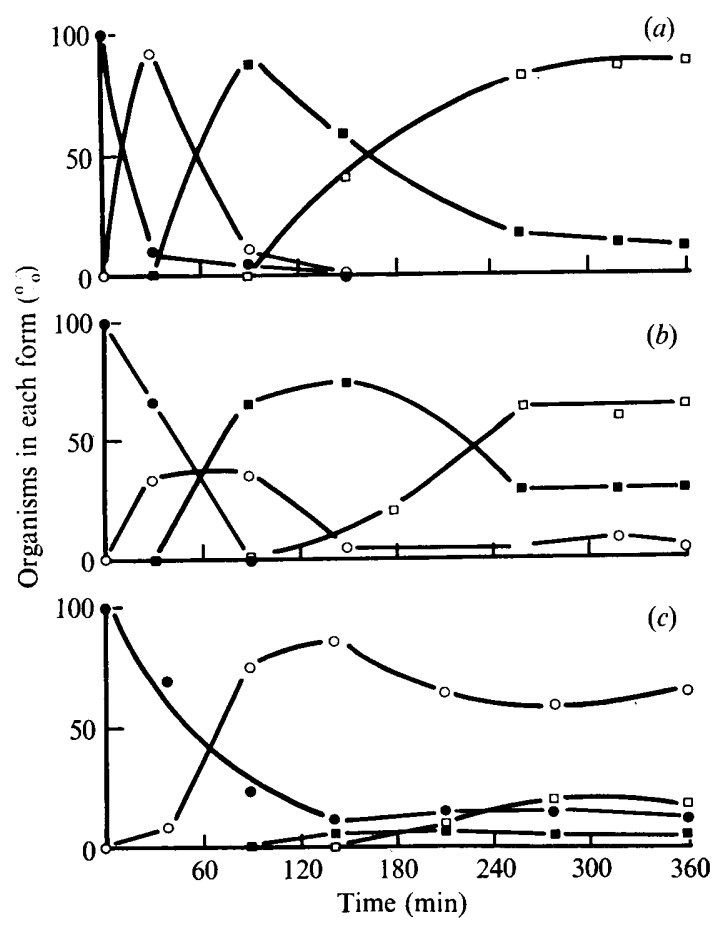

Fig. I. Effect of chlorine and heat on the germination and outgrowth of spores of $B$. subtilis. Spores of $B$. subtilis were incubated in heart infusion broth $(a)$ without chlorine treatment, $(b)$ after treatment with $50 \mu \mathrm{g}$ chlorine $/ \mathrm{ml}$ as described in Methods, or (c) after treatment with $50 \mu \mathrm{g}$ chlorine $/ \mathrm{ml}$ and heating at $80^{\circ} \mathrm{C}$ for $10 \mathrm{~min}$. Samples were removed at intervals and the percentage of refractile (O), non-refractile $(\bigcirc)$, swollen $(\square)$ or elongated $(\square)$ spores determined by counting IOO organisms by phase contrast microscopy.

\section{RESULTS}

\section{Effect of chlorine on germination, outgrowth and colony formation}

The development of a vegetative bacterium from a bacterial spore involves loss of refractility (germination) followed by swelling and elongation of the germinated spore (outgrowth). With $B$. subtilis most untreated spores had lost refractility by $30 \mathrm{~min}$, had swollen by $90 \mathrm{~min}$, and had elongated to form vegetative organisms by $5 \mathrm{~h}$ (Fig. I $a$ ). After treatment with $25 \mu \mathrm{g}$ free chlorine/ml these processes were only slightly delayed but, while treatment with $50 \mu \mathrm{g}$ free chlorine/ml markedly retarded outgrowth (Fig. I $b$ ), I00 $\mu \mathrm{g}$ free chlorine $/ \mathrm{ml}$ prevented germination within $6 \mathrm{~h}$. A similar effect was obtained with spores of $B$. cereus, except that treatment with $50 \mu \mathrm{g}$ free chlorine $/ \mathrm{ml}$ prevented germination. With spores of $C$. bifermentans, treatment with $20 \mu \mathrm{g}$ free chlorine $/ \mathrm{ml}$ markedly delayed outgrowth (Fig. 2), while $50 \mu \mathrm{g}$ free chlorine $/ \mathrm{ml}$ allowed about $60 \%$ to germinate within $6 \mathrm{~h}$ but completely prevented swelling. After treatment with chlorine, the percentage of viable spores, measured by colony-forming ability, was quantitatively similar to the percentage of spores able to form vegetative bacteria except that in some experiments the appearance of colonies was delayed. A slow-germinating mutant of $C$. bifermentans whose germination was markedly increased by chlorine treatment (Wyatt \& Waites, 1973) was also examined. Colony formation from spores of the mutant was less sensitive to chlorine than it was with the parent strain; for example, when treated with $10 \mu \mathrm{g}$ free chlorine $/ \mathrm{ml}$ for 10,30 or $60 \mathrm{~min}$, 

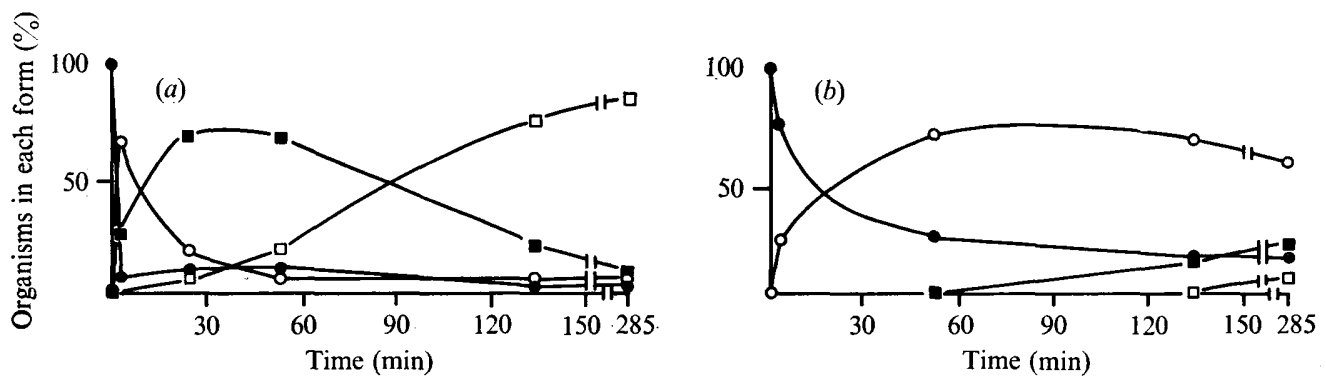

Fig. 2. Effect of chlorine on the germination and outgrowth of spores of $C$. bifermentans. Spores of $C$. bifermentans were incubated in a medium containing casein hydrolysate, $(a)$ without chlorine treatment or $(b)$ after treatment with $20 \mu \mathrm{g}$ chlorine $/ \mathrm{ml}$ as described in Methods. Symbols as for Fig. I.

Table I. Effect of heat on germination of spores after treatment with chlorine

Spores of $C$. bifermentans, B. cereus and B. subtilis were treated with chlorine at the concentrations described and then germinated either with or without heating as described in Methods.

\begin{tabular}{|c|c|c|c|c|c|c|}
\hline \multirow{3}{*}{$\begin{array}{c}\text { Chlorine concn } \\
(\mu \mathrm{g} \text { free chlorine } / \mathrm{ml})\end{array}$} & \multicolumn{6}{|c|}{$\begin{array}{l}\text { Germination rate } \\
(\% / \mathrm{min})\end{array}$} \\
\hline & \multicolumn{2}{|c|}{ C. bifermentans } & \multicolumn{2}{|c|}{ B. cereus } & \multicolumn{2}{|c|}{ B. subtilis } \\
\hline & Unheated & Heated & Unheated & Heated & Unheated & Heated \\
\hline 0 & 56 & 57 & 22 & 38 & $7 \cdot 9$ & $7 \cdot \mathrm{I}$ \\
\hline 10 & 24 & 19 & 25 & 48 & - & - \\
\hline 20 & 0.4 & 0.3 & 19 & $5 \cdot 6$ & $\cdots$ & - \\
\hline 30 & - & - & $2 \cdot 5$ & $2 \cdot 5$ & $5 \cdot 8$ & $3 \cdot 0$ \\
\hline 40 & 0.02 & $*$ & - & - & - & 一 \\
\hline 50 & $*$ & $*$ & $I \cdot O$ & $<0.2$ & $3 \cdot 3$ & $I \cdot 5$ \\
\hline 100 & $*$ & $*$ & - & - & 0.002 & 0.001 \\
\hline 150 & - & - & - & 一 & $<0.001$ & $*$ \\
\hline
\end{tabular}

* Some spores had lost refractility before addition of germinants.

the number of colonies formed by each strain (expressed as a percentage of the colonies formed by untreated spores) was 35,13 or $1.0 \%$ for the parent and 47,43 or $35 \%$ for the mutant.

\section{Effect of heat on spores treated with chlorine}

Dye \& Mead (1972) showed that colony formation by spores of $C$. bifermentans and $C$. perfringens which survived treatment with chlorine, was more sensitive to heat than that of untreated spores. In the present study with B. subtilis, B. cereus and C. bifermentans, after chlorine treatment had reduced the colonies formed to $\mathrm{I} \%$, a heat treatment reduced the colonies formed to $0.2 \%$. After less severe chlorine treatments heating did not reduce the percentage of survivors.

Chlorine-treated spores of $C$. bifermentans and B. subtilis germinated more slowly after heating, but those of $B$. cereus which require heat activation (Keynan et al. I964) germinated more rapidly after heating following treatment with $10 \mu \mathrm{g}$ free chlorine $/ \mathrm{ml}$ (Table I). Heating also slowed the elongation of spores of $B$. subtilis pretreated with $50 \mu \mathrm{g}$ free chlorine/ $\mathrm{ml}$ (Fig. I c) but did not significantly delay outgrowth of spores treated with $25 \mu \mathrm{g}$ or less of free chlorine/ml. 


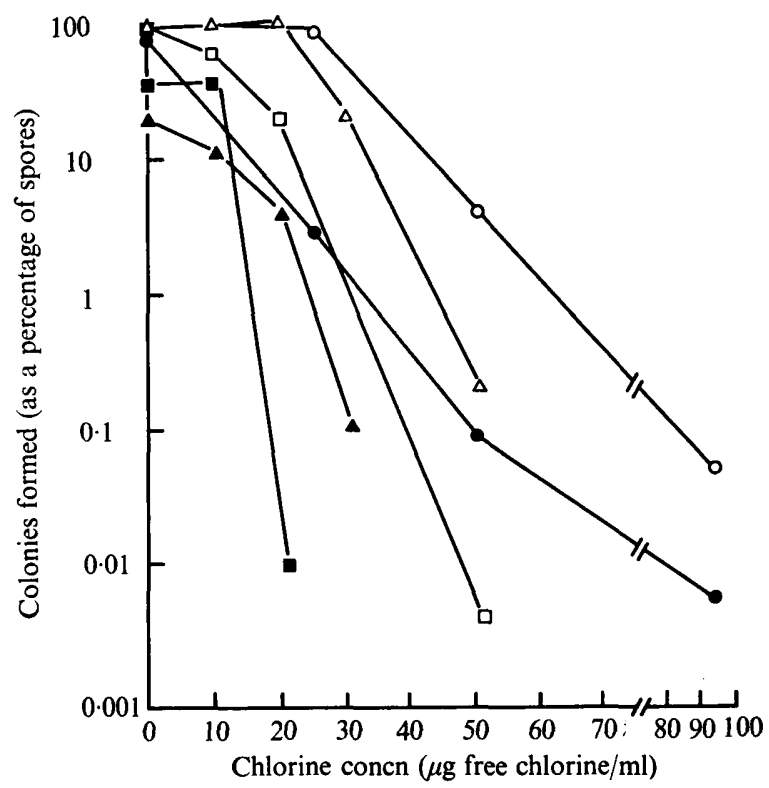

Fig. 3. Effect of chlorine on the colony-forming ability of spores pretreated with dithiothreitol or dithiothreitol-urea. Spores pretreated (closed symbols) or not (open symbols) with dithiothreitol (C. bifermentans, $\square, \square$ ) or dithiothreitol-urea $(B$. cereus, $\boldsymbol{\Delta}, \triangle$ and $B$. subtilis $\bigcirc, \bigcirc)$ were treated with chlorine at the concentrations described and the percentage of spores able to form colonies determined as described in Methods.

Table 2. Effect of lysozyme on germination of spores of $C$. bifermentans after treatment with chlorine

Spores were treated with the concentrations of chlorine indicated, and then incubated either at $4{ }^{\circ} \mathrm{C}$ in glass-distilled water for 7 days, or at $37^{\circ} \mathrm{C}$ for $20 \mathrm{~h}$ in sodium phosphate buffer $(83 \mathrm{~mm}$, $\mathrm{pH} 7 \cdot 0$ ) with or without lysozyme at $100 \mu \mathrm{g} / \mathrm{ml}$.

Percentage of non-refractile spores after treatment with:

Chlorine concn ( $\mu \mathrm{g}$ free chlorine $/ \mathrm{ml}$ )

$\begin{array}{ccr}\text { Glass-distilled water } & \begin{array}{c}\text { Sodium phosphate } \\ \text { buffer }\end{array} & \begin{array}{c}\text { Sodium phosp } \\ \text { plus lyso }\end{array} \\ 2 & \text { I } & 6 \\ 3 & 7 & 39 \\ 2 & 8 & 69 \\ \text { I4 } & 98 & 78 \\ \text { 5I } & - & -\end{array}$

\section{Effect of chlorine on spore constituents}

Dithiothreitol, dithiothreitol with urea, or urea with mercaptoethanol, have been shown to remove protein from spore coats without affecting colony formation (Aronson \& FitzJames, 1971). Pretreatment with such agents markedly reduced the ability of spores of $B$. subtilis and $B$. cereus to form colonies after subsequent treatment with chlorine; results for dithiothreitol with urea are shown in Fig. 3. With C. bifermentans, dithiothreitol had a similar effect (Fig. 3). The other pretreatments were not tested with $C$. bifermentans because they markedly reduced colony formation even in the absence of chlorine treatment. Polyacrylamide gel electrophoresis of protein extracted from spores of B. subtilis, B. cereus or $C$. bifermentans, by dithiothreitol-urea or a solution containing Io $\mathrm{mg}$ free chlorine $/ \mathrm{ml}$, 
Table 3. Effect of lysozyme on colony formation after treatment of spores of C. bifermentans with chlorine

Spores of $C$. bifermentans were treated with chlorine at the concentration described, spread on reinforced clostridial medium solidified with $\mathrm{I} \cdot 5 \%$ agar containing $0, \mathrm{I} \cdot 0,2.5$ or $5 \cdot 0 \mu \mathrm{g}$ lysozyme $/ \mathrm{ml}$, and incubated as described in Methods.

Chlorine conen ( $\mu \mathrm{g}$ free chlorine/ml)

0

10

50
$10^{-7} \times$ Colonies formed $/ \mathrm{ml}$, at lysozyme concn of $(\mu \mathrm{g} / \mathrm{ml})$ :

$\begin{array}{cccc}0 & 1 \cdot 0 & 2.5 & 5 \cdot 0 \\ 92 & 100 & 93 & 80 \\ 24 & 24 & 29 & 24 \\ 3.5 & 4.8 & 4.9 & 4 . \mathrm{I}\end{array}$

produced an identical band to that extracted from spore coats of $C$. bifermentans by sodium hydroxide (Wyatt \& Waites, I97I; Waites, Wyatt \& Arthur, 1972), although other less dense bands similar to those demonstrated by Vary (1973) were also found in the dithiothreitol-urea extracts. Since agents which remove spore coat are known to allow germination by lysozyme (Gould, Stubbs \& King, 1970; Aronson \& Fitz-James, 197I ; Wyatt \& Waites, I974), we examined the ability of lysozyme to promote germination of spores of C. bifermentans after treatment with chlorine (Table 2). Spores treated with $20 \mu \mathrm{g}$ free chlorine/mi lost refractility with lysozyme but from the periphery only, the centre remaining refractile, while spores treated with $40 \mu \mathrm{g}$ free chlorine $/ \mathrm{ml}$ lost peripheral refractility on incubation in the absence of lysozyme, as did spores of $B$. subtilis treated with $100 \mu \mathrm{g}$ free chlorine $/ \mathrm{ml}$. Heating increased twofold the number of spores of $C$. bifermentans which lost refractility with lysozyme after treatment with $10 \mu \mathrm{g}$ free chlorine $/ \mathrm{ml}$.

Lysozyme $(5 \mu \mathrm{g} / \mathrm{ml})$ in the medium did not increase the colony formation of spores of C. bifermentans treated with Io or $50 \mu \mathrm{g}$ free chlorine $/ \mathrm{ml}$ by more than $5 \%$ (Table 3 ), and similar results were obtained with $B$. subtilis after treatment with 25 or $50 \mu \mathrm{g}$ free chlorine/ $\mathrm{ml}$. It is apparent, therefore, that when chlorine damages the spore coat sufficiently to allow lysozyme to initiate germination, it usually also damages the spore sufficiently to prevent outgrowth of the germinated spore.

\section{DISCUSSION}

We have shown that chlorineprevents colony formation by spores of $B$. subtilis, B. cereus and $C$. bifermentans by preventing germination or swelling. After treatment with chlorine, germination, outgrowth and colony formation were all more sensitive to heat. Chlorine removed a protein from spores of B. subtilis, B. cereus and C. bifermentans which had the same electrophoretic mobility on polyacrylamide gel as the protein removed from spore coats of $C$. bifermentans by sodium hydroxide (Wyatt \& Waites, 1971; Waites et al. 1972). Mild treatments with either sodium hydroxide or chlorine increase the germination rate of slow-germinating mutants of $C$. bifermentans (Wyatt \& Waites, 1971, 1973), perhaps by removing protein and increasing the permeability of the spore to germinants, while the coats of spores treated with higher concentrations of chlorine were sufficiently permeable to allow lysozyme to promote germination. Such results, together with the loss of dipicolinic acid from spores after treatment with chlorine (Alderton \& Halbrook, I97I ; Dye \& Mead, 1972) and the germination-like changes which occurred during incubation in water of spores treated with high concentrations of chlorine, suggest that chlorine disrupts first the spore coat and secondly layers nearer to the spore centre; at any rate 
where chlorine inactivated the germination mechanism, even when lysozyme was able to initiate germination, most spores were damaged to the extent that further development was prevented.

Vary (1973) has shown that sodium hydroxide and other treatments which remove protein from spores of Bacillus megaterium also increase the germination rate and in some cases allow germination to occur with a wider variety of compounds. We have found similar effects with C. bifermentans (Waites et al. 1972). Neither we nor Vary have found that such procedures decrease the heat resistance of spores, in contrast to the effect of chlorine.

Germination and colony formation of the slowly germinating mutant I (Wyatt \& Waites, I973) were more resistant to chlorine than was the case with the parent strain. Germination of spores of mutant I was previously found to be more resistant to successive treatments with sodium hydroxide and lysozyme (Wyatt \& Waites, 1974). Since sodium hydroxide and chlorine allow lysozyme to degrade the spore cortex by increasing the permeability of the spore coat, differences in the spore coat between the wild type and mutant I may account for differences in resistance to both chlorine and sodium hydroxide. We have found that treatments which remove spore-coat protein increase the lethal effect of chlorine on spores of $C$. bifermentans, B. subtilis and B. cereus by as much as $4000-$ fold (Fig. 3). These results suggest that the coat protects spores against chlorine. The coat may also protect spores against other chemicals, since Freese et al. (1970) showed that spores of B. subtilis which were deficient in cortex but had apparently normal coats were resistant to octanol. However, since spores treated with urea-mercaptoethanol are about Ioo times more resistant than vegetative cells to chlorine (cf. Phillips, I952), then either some remaining coat material protects the spores or the inner layers of the spore have properties which confer extra resistance.

We are grateful to Dr G. C. Mead and Dr J. L. Peel for useful discussions.

\section{REFERENCES}

Alderton, G. \& Halbrook, W. U. (I97I). Action of chlorine on bacterial spores. Bacteriological Proceedings, 12.

Aronson, A. I. \& Fitz-James, P. C. (I97I). Reconstitution of bacterial spore coat layers in vitro. Journal of Bacteriology ro8, $57 \mathrm{I}-578$.

Davis, B. J. \& Ornstein, L. (I96I). Disc Electrophoresis. Rochester, U.S.A.: Distillation Products Industries.

Dye, M. \& MeAD, G. C. (1972). The effect of chlorine on the viability of clostridial spores. Journal of Food Technology 7, 173-181.

Freese, E. B., Cole, R. M., Klofat, W. \& Freese, E. (I970). Growth, sporulation and enzyme defects of glucosamine mutants of Bacillus subtilis. Journal of Bacteriology ror, 1046-1062.

Gould, G. W. \& Hitchins, A. D. (I963). Sensitization of bacterial spores to lysozyme and to hydrogen peroxide with agents which rupture disulphide bonds. Journal of General Microbiology 33, 4I3-423.

Gould, G. W., StubBs, J. M. \& KING, W. L. (1970). Structure and composition of resistance layers in bacterial spore coats. Journal of General Microbiology 6o, 347-355.

Hirsch, A. \& Grinsted, E. (1954). Methods for the growth and enumeration of anaerobic spore-formers from cheese with observations on the effect of nisin. Journal of Dairy Research 21, IOI-I IO.

Keynan, A., Evenchik, Z., Halvorson, H. O. \& Hastings, J. W. (I964). Activation of bacterial endospores. Journal of Bacteriology 88, 3 I 3-3 18.

Knox, W. F., Stumpf, P. K., Green, D. E. \& Auerbach, V. H. (I948). The inhibition of sulfhydryl enzymes as the basis of the bactericidal action of chlorine. Journal of Bacteriology 55, 45 I-458.

Lowry, O. H., Rosebrough, N. J., FArR, A. L. \& Randall, R. J. (I95I). Protein measurement with the Folin phenol reagent. Journal of Biological Chemistry 193, 265-275.

Palin, A. T. (1957). The determination of free and combined chlorine in water by the use of diethyl-pphenylene diamine. Journal of the American Water Works Association 49, 873-880. 
Phillips, C. R. (1952). Relative resistance of bacterial spores and vegetative bacteria to disinfectants. Bacteriological Reviews 16, 135-138.

Trueman, J. R. (1971). The halogens. In Inhibition and Destruction of the Microbial Cell, pp. 137-I83. Edited by W. B. Hugo. London: Academic Press.

VARY, J. C. (I973). Germination of Bacillus megaterium spores after various extraction procedures. Journal of Bacteriology 116, 797-802.

WAITES, W. M. \& WyATt, L. R. (197I). Germination of spores of Clostridium bifermentans by certain amino acids, lactate and pyruvate in the presence of sodium or potassium ions. Journal of General Microbiology 67, 21 5-222.

Waites, W. M. \& WyatT, L. R. (1974). The outgrowth of spores of Clostridium bifermentans. Journal of General Microbiology 84, 235-244.

Waites, W. M., Wyatt, L. R. \& ARthur, B. (1972). Effect of alkali treatment on the germination and morphology of spores of Clostridium bifermentans. In Spores V, pp. 430-436. Edited by H. O. Halvorson, R. Hanson and L. L. Campbell. Washington, D.C.: American Society for Microbiology.

WyAtT, L. R. \& WAItes, W. M. (I97I). Studies with spores of Clostridium bifermentans: comparison of germination mutants. In Spore Research-197I, pp. I23-I3I. Edited by A. N. Barker, G. W. Gould and J. Wolf. London: Academic Press.

WyATT, L. R. \& WAITES, W. M. (I973). The effect of hypochlorite on the germination of spores of Clostridium bifermentans. Journal of General Microbiology 78, 383-385.

WyatT, L. R. \& WAItES, W. M. (1974). The effect of sodium hydroxide or dithiothreitol-urea on spores of germination mutants of Clostridium bifermentans. Journal of General Microbiology 84, 39I-394. 